\title{
Grazing Intensity on Vegetation Dynamics of a Typical Steppe in Northeast Inner Mongolia
}

\author{
Yan Liang, ${ }^{1}$ Guodong Han, ${ }^{2} \mathrm{He}$ Zhou, ${ }^{3}$ Mengli Zhao, ${ }^{2}$ Hennie A. Snyman, ${ }^{4}$ \\ Dan Shan, ${ }^{5}$ and Kris M. Havstad ${ }^{6}$
}

Authors are ${ }^{1}$ Research Associate and ${ }^{3}$ Professor, Rangeland Ecology, Department of Grassland Science, College of Animal Science and Technology, China Agricultural University, Beijing 100193, People's Republic of China; ${ }^{2}$ Professors of Rangeland Ecology and ${ }^{5}$ Research Associate, Rangeland Ecology, Inner Mongolia Agricultural University, Huhhot, Inner Mongolia 010018, People's Republic of China; ${ }^{4}$ Professor, Rangeland Ecology, Department of Animal, Wildlife, and Grassland Sciences, University of the Free State, PO Box 339, Bloemfontein 9300, South Africa; and ${ }^{6}$ Supervisory Scientist, US

Department of Agriculture-Agricultural Research Service Jornada Experimental Range, New Mexico State University, Las Cruces, NM 88003-0003, USA.

\begin{abstract}
Vegetation features radiating from residential areas in response to livestock grazing were quantified for an arid steppe rangeland in the Keshiketeng Banner, Chifeng Prefecture, in northeastern Inner Mongolia in 2004 and 2006. The aim of this study was to estimate grazing impacts on the vegetation dynamics of these historical grazed ecosystems. Grazing intensities were classified as reference area (RA), light (LG), moderate (MG), and heavy (HG) according to the vegetation utilization across the study area. Rangelands were studied along a grazing gradient, where characteristics of plant communities, heights of dominant species, aboveground vertical structures, and belowground biomass were investigated. Along this grazing gradient, vegetation changed from the original dominant plant species Leymus chinensis (Trin.) Tzvel. to a semi-subshrub species Artemisia frigida Willd. when moving from the reference area (RA) to the region around the settlement. Canopy coverage, aboveground productivity, and the number of perennial species declined as one moved toward the residential area. Heights of five dominant species, except for Stipa grandis P. Smirn., declined with increased grazing intensity. Aboveground vertical structure in the RA treatment showed more resilience than the other treatments. There was no difference in root biomass in the top $1 \mathrm{~m}$ of soil $(P>0.05)$ between the RA treatment and the area immediately around settlement (HG treatment). Generally, we found that the intensity of grazing disturbance did not exceed the tolerance of the rangeland ecosystem within LG treatment. However, vegetative conditions in HG treatment became worse with increased grazing pressure. Rangelands in this arid steppe are under tremendous threat due to excessive forage utilization, which cannot be considered a sustainable practice.
\end{abstract}

\section{Resumen}

Las características de la vegetación en áreas residenciales en respuesta al pastoreo de ganado fueron cuantificadas en un pastizal estepario árido en Keshiketeng Banner, del noreste de Mongolia en 2004 y 2006. El objetivo de este estudio fue estimar los impactos del pastoreo en la dinámica de la vegetación de estos ecosistemas pastoreados históricamente. Las intensidades de pastoreo fueron clasificadas como un área de referencia (RA), ligero (LG), moderado (MG), y pesado (HG) según la utilización de la vegetación a través del área de estudio. Los pastizales fueron estudiados a lo largo de un gradiente del pastoreo, donde las características de las comunidades de la planta, las alturas de las especies dominantes, sobre las estructuras verticales, y la biomasa subterránea se investigaron. A lo largo de este gradiente de pastoreo la vegetación cambió de la especie original dominante Leymus chinensis (Trin.) Tzvel. a un Artemisia frigida Willd. en la medida que se movía del RA a la región hasta el establecimiento de (HG). La cobertura del follaje, la productividad aérea y el número de especies perennes disminuyeron con el movimiento hacia el área residencial. Las alturas de cinco especies dominantes, a excepción de los Stipa grandis P. Smirn. disminuyeron con incrementos en la intensidad d pastoreo. La estructura vertical aérea en el tratamiento RA presentó un modelo más resistente que los otros tratamientos. No se observaron diferencias $(P>0.05)$ en la biomasa de la raíz en a $1 \mathrm{~m}$ de la superficie del suelo entre RA y el área inmediatamente alrededor del establecimiento (tratamiento de pastoreo pesado). En general, se encontró que el disturbio debido a la intensidad del pastoreo no excedió la tolerancia del ecosistema del pastizal dentro del tratamiento LG. Sin embargo, las condiciones vegetativas en el tratamiento HG llegaron a ser pésimas con incrementos en la presión de pastoreo. Los pastizales de esta estepa árida están bajo enormes amenazas debido a la utilización excesiva del forraje que no pueden ser consideradas como prácticas sostenibles.

Key Words: Inner Mongolia grasslands, forage utilization, grazed ecosystem, plant-herbivore interactions

Research was funded in part by National Key Fundamental Research and Development Fund of China (No. 2007CB106800) and the National Natural Science Foundation of China (No. 30360022).

Correspondence: He Zhou, Dept of Grassland Science, College of Animal Science and Technology, China Agricultural University, Beijing 100193, People's Republic of China. Email: zhouhe@cau.edu.cn

Manuscript received 18 July 2008; manuscript accepted 23 February 2009.

\section{INTRODUCTION}

Livestock grazing represents an important and historical use of rangelands (Chang and Xia 1994; Snyman 1998). However, for the world's arid and semiarid rangelands, overgrazing consistently has been one of the most important causes of degradation (Belsky 1987; Li and Wang 1999; Wiegand et al. 
2004; Snyman 2005; Su et al. 2005; Van der Westhuizen et al. 2005). Overgrazing results in a number of negative impacts, often including an increase in undesirable vegetation or a loss in vegetation cover and biomass (O'Connor et al. 2001; Friedel et al. 2003; Tongway et al. 2003). Direct livestock grazing effects include plant consumption and trampling that can destroy the structure and composition of the plant communities (Kraaij and Milton 2006). Indirect effects, such as reduction in soil organic matter inputs, can negatively impact important abiotic elements (Wang 2004). Understanding vegetation dynamics in grazed rangeland systems often has been hampered by our inability to adequately uncouple the biotic and abiotic determinants of vegetative change that adequately portray ecosystem responses to grazing (Kraaij and Milton 2006). Effects of overgrazing can be insidious, and resulting impacts can be nearly or wholly irreversible.

Sward vegetation is an essential component of rangeland ecosystems and is the most important practical benefit of rangeland use; therefore, the restoration of rangeland ecosystems is often directed towards recovery of the vegetation sward (Bao and Chen 1999; Swemmer et al. 2007). Belowground biomass production includes that of rhizomes, root stock, bulbs, and tubers. Roots are important organs to absorb water and nutrition from soil, and moreover, as storage organs for organic matter (Snyman and Du Preez 2005), and as the manufacturing organs for various hormones and growth regulators. In rangeland ecosystems, roots are the major transporters of nitrogen and ash content elements in the cycle from the soil to the plant (Du Preez and Snyman 1993). Therefore, it is meaningful to examine the root system when studying the structure and function of ecosystems.

Selecting the correct stocking rate is one of the most important grazing management decisions, and should be based on sustainable use of vegetation by grazing animals (including livestock and wildlife populations) and production, and not solely on economic returns (Snyman 1998; Van der Westhuizen et al. 2001). Another important principle in grazing management is properly distributing grazing use across a landscape.

In China, specific areas with noticeable rangeland degradation are found in the northern steppe, the western desert steppe, and the alpine steppe of the Qinghai-Tibet Plateau (Liao and Jia 1996). The level of degradation of Inner Mongolia's rangeland is among the most serious in China. Chifeng City Prefecture contains some of the most degraded rangelands in northeast Inner Mongolia, with $84 \%$ of the total rangeland degraded (Du 2006). This study describes the present condition of rangelands near the Chifeng City Prefecture under domestic family management. Much of this grazing use is strongly influenced by watering points and stocking rates. Our principal objective was to quantify grazing impacts on the vegetation dynamics of these historically grazed ecosystems.

\section{MATERIALS AND METHODS}

\section{Study Site}

This study site was representative of the surrounding region in the Inner Mongolia plateau to the southwest of the great Khingan mountain and northwest of the Chifeng City Prefecture in Inner Mongolia, China (lat $116^{\circ} 38^{\prime}-116^{\circ} 41^{\prime} \mathrm{N}$, long $43^{\circ} 25^{\prime}-43^{\circ} 27^{\prime} \mathrm{E}$, altitude $1286 \mathrm{~m}$ ). The climate is continental, with significant diurnal temperature changes, cold winters, and frequent windy periods. The following attributes apply throughout the area: mean annual temperature of $1-2^{\circ} \mathrm{C}$, average annual cumulative temperature higher than $10^{\circ} \mathrm{C}$ is $1300-1700^{\circ} \mathrm{C}$, mean annual total sunshine of $2700-2900 \mathrm{~h}$, annual radiation of $57-58 \mathrm{~J} \cdot \mathrm{cm}^{-2}$, average annual precipitation of $350-400 \mathrm{~mm}$ with $60-80 \mathrm{~d}$ verdant (growing season April-September). The soil is a Kastanozems (Mollisols in World References Base for Soil Resources). Soil $(0-20 \mathrm{~cm})$ throughout the study area is classified as loamy texture with sand content at $59.6 \pm 0.6 \%$, silt at $23.8 \pm 0.4 \%$, and clay at $16.7 \pm 0.4 \%$ (based on 45 soil samples). Typical $\mathrm{pH}$ range within $0-5 \mathrm{~cm}$ topsoil is $7.32 \sim 7.79$ and soil bulk density is $1.16 \pm 0.07 \mathrm{~g} \cdot \mathrm{m}^{-3}$. Soils freeze to a maximum depth of about $1910 \mathrm{~mm}$ during the winter. Vegetation is characterized as typical steppe, dominated by Leymus chinensis (Trin.) Tzvel., Stipa grandis P. Smirn., and Cleistogenes squarrosa (Trin.) Keng. Main associate species are Artemisia frigida Willd., Potentilla acaulis L., and Carex duriuscula C. A. Mey. A. frigidia is a subshrub; the other plant species mentioned are all herbaceous plants.

A hayed enclosure and a residential area are situated at the north and south of the study site, respectively, and the distance between them is $4 \mathrm{~km}$. The width of the study site (from east to west) is $3.6 \mathrm{~km}$. The area (approximately $1330 \mathrm{ha}$ ) is utilized by family ranches (households) who live in a fixed residential zone. Approximately 3900 sheep and 800 cattle graze freely (communal grazing) on the rangeland for most of the year, which translates to an overall stocking rate of 6.53 sheep $\cdot \mathrm{ha}^{-1}$. Supplementary feedings are applied during the winter. Animals are housed or yarded at night near the residential area but graze freely during the day as they move outward from the residential area. There is an enclosed (ungrazed) area $4.1 \mathrm{~km}$ from the residential area that is used to produce hay. The hay is cut each year in mid-August when most of the grasses have matured and set seeds. Because this zone has been fenced off since the 1970s and is furthest from the residential area, it was considered to be a "least degraded" treatment and served as the benchmark for the study site. At the same time, we recognized that the botanical composition of the ungrazed area might have shifted toward an overrepresentation of species favored by cutting conditions. For reasons of convenience and due to the time required for animals to walk to the outlying parts of the rangeland, there was a distinct decrease in grazing pressure with increasing distance from the residential area. Vegetation conditions showed a gradual change as one moved from the settlement to the area around the enclosure. However, we also recognized that the change in vegetation not only might be the result of differences in grazing intensity but also the result of the environment factors. Although we had no positive proof to clarify the association between grazing and vegetative differences, the phenomenon that vegetation communities coexisted under different conditions was apparent. The emphasis of this study was to quantify the current rangeland vegetation conditions of this region.

\section{Treatments}

The reference area (RA) was at the edge of a hayed enclosure, $4.1 \mathrm{~km}$ from the residential area; the width of the edge was 
Table 1. Grazing utilization (\%; mean \pm SE; $n=9$ ) in accordance with grazing intensities for 2004, 2006, and 2007.

\begin{tabular}{cccc}
\hline & $\mathrm{LG}^{1}$ & $\mathrm{MG}^{1}$ & $\mathrm{HG}^{1}$ \\
\hline & & & \\
2004 & $18 \pm 1.96$ & $41 \pm 2.22$ & $68 \pm 1.95$ \\
2006 & $15 \pm 1.21$ & $36 \pm 2.44$ & $62 \pm 2.56$ \\
2007 & $19 \pm 1.82$ & $44 \pm 2.41$ & $65 \pm 2.48$ \\
\hline
\end{tabular}

${ }^{1} \mathrm{LG}$ indicates light grazing; MG, moderate grazing; and $\mathrm{HG}$, heavy grazing.

about $4 \mathrm{~m}$ and has been free from any disturbance by mowing for more than $30 \mathrm{yr}$. Three sample belts extending away from the residential area toward the direction of hayed enclosure were laid out at $1-\mathrm{km}$ intervals. Three relative grazing intensity zones were classified as light (LG), moderate (MG), and heavy (HG), according to estimations of differences in ground coverage (conducted in 2004 and 2006) and forage utilization (conducted in 2004, 2006, and 2007). Fifteen quadrats (20 × $50 \mathrm{~cm}^{2}$ ) representing ground coverage under different grazing intensities within the three sample belts (five on each line) were sampled at the midpoint of each zone once in August in 2004 and 2006, respectively. Forage utilization was quantified along these gradients. To measure forage utilization, three moveable forage cages $\left(1.5 \times 1.5 \mathrm{~m}^{2}\right)$ in each zone and within each of the three sample belts along the gradient were fixed before herding of livestock in spring 2004, 2006, and 2007. The biomass inside and outside the forage cages (nine in each zone) was estimated in August 2004, 2006, and 2007. Utilization rate was calculated by the difference between inside and outside biomass divided by the biomass inside the cages (Ren 1998) and is presented in Table 1.

\section{Measurement of Communities and Dominant Species Heights}

Twelve randomly selected quadrats were sampled in August 2004 and again in August 2006 along the three sample belts and within each zone of grazing intensity. The quadrats were 1 $\times 1 \mathrm{~m}$. Botanical composition, plant height, and canopy cover were measured, and plant species richness was calculated in the quadrats, and all plants were harvested at ground level, ovendried for $24 \mathrm{~h}$ at $80^{\circ} \mathrm{C}$, and weighed to the nearest $0.1 \mathrm{~g}$. (Ren 1998).

When measuring heights of dominant species, only mature plants in good condition were randomly picked to avoid bias from presence of seedlings or abnormal growth. The reproductive height of herbaceous plants was determined as the maximum height of branches having flowers or fruits. In the case of $A$. frigida, we measured the height of erect reproductive branches as its reproductive height. Foliage layer heights were the heights of the highest leaves of an individual plant (Ren 1998).

\section{Measurement of Aboveground Vertical Structures}

Aboveground vertical structures were collected on 20 August 2004. Nine quadrats $(1 \times 1 \mathrm{~m})$ in each zone were randomly selected. Within each quadrat, parts of each individual plant were collected every $5 \mathrm{~cm}$ according to their natural growth height. The plant parts of the same height within each quadrat were then pooled and weighed after being oven dried at $65^{\circ} \mathrm{C}$ for $24 \mathrm{~h}$ (Ren 1998).

\section{Measurement of Belowground Biomass}

Root mass measurements were conducted in August 2004 and 2006. Rectangular parallel piped samples $(20 \times 30 \times 10 \mathrm{~cm})$ were taken randomly in each treatment in August and 10 layers were removed for a total sampling depth of $1 \mathrm{~m}$. Five replications were applied in each zone (three per sample belt within each zone). A 2-mm mesh sieve was used to wash the sample soils successively to filter out the majority of roots, and fine roots were caught by spreading the remaining soil in a shallow tray. The outflow from this tray passed through a $0.5-\mathrm{mm}$ mesh sieve. No attempt was made to distinguish between live and dead roots. All biomass (above- and belowground) was weighed after oven-drying at $80^{\circ} \mathrm{C}$ (Ren 1998).

\section{Statistical and Data Analysis}

The data were analyzed as a randomized complete block design with three sample belts and four treatments. The treatment effect was tested by the treatment $\times$ replicate interaction. Data were analyzed using the analysis of variance (ANOVA) procedure of SAS (SAS 8.1) statistical programming package (Pei and Xue 1998). Results on all variables were considered significant if $P$ values were less than or equal to 0.05 . Significant differences among means were found to be normally distributed using the Shapiro-Wilk test for normality (Xin and Jiang 2001). In the ANOVA test, significant differences among means were identified using the protected least significant difference (LSD) method (Pei and Xue 1998; Xin and Jiang 2001).

Data were collected as repeated measures and analyses were conducted using the SAS (8.1) statistical programming package (Pei and Xue 1998). Analyses of zone effects, regarded as in situ treatments, were conducted with one-way ANOVA in SAS (8.1). Results on all variables were considered significant if $P$ values were less than or equal to 0.05 . Significant differences among means were found to be normally distributed using the Shapiro-Wilk test for normality (Xin and Jiang 2001). In the ANOVA tests, significant differences among means were identified using the protected least significant difference (LSD) method (Pei and Xue 1998; Xin and Jiang 2001).

\section{RESULTS}

\section{Community Characteristics}

The number of perennial species was similar between RA and LG areas $(P>0.05)$ and between MG and HG areas $(P>0.05$; Table 2). However there were about twice as many total species in the RA and LG areas than in the MG and HG areas. For 2004, the RA treatment had the lowest $(P<0.05)$ number of annual species, and there were no significant differences among the other three treatments $(P>0.05)$; however, the values were similar $(P>0.05)$ among each treatment in 2006 . Among the four grazing intensities in 2004, canopy coverage was higher $(P<0.05)$ for RA and LG, and lower $(P>0.05)$ for MG and HG; but was the same level between RA and LG, and between MG and HG $(P>0.05)$. For 2006, the canopy coverage value for RA was similar $(P>0.05)$ to $L G$, higher $(P<0.05)$ than MG, and lowest $(P<0.05)$ in HG. We detected that in both years, the original dominant species L. chinensis in 
Table 2. Community characteristics of dominant species, number of perennial and annual species, and coverage in response to grazing intensities for 2004 and 2006.

\begin{tabular}{|c|c|c|c|c|}
\hline & Dominant species & No. perennial species & No. annual species & Canopy coverage $(\%)$ \\
\hline \multicolumn{5}{|l|}{2004} \\
\hline $\mathrm{RA}^{1}$ & Leymus chinensis (Trin.) Tzvel. & $42 \pm 3.1 \mathrm{a}^{2}$ & $8 \pm 3.5 b$ & $77 \pm 3.1 \mathrm{a}$ \\
\hline$L G$ & Leymus chinensis (Trin.) Tzvel.; Cleistogenes squarrosa (Trin.) Keng & $41 \pm 3.6 \mathrm{a}$ & $11 \pm 1.8 \mathrm{a}$ & $60 \pm 5.2 \mathrm{a}$ \\
\hline MG & Leymus chinensis (Trin.) Tzvel.; Cleistogenes squarrosa (Trin.) Keng & $26 \pm 5.5 b$ & $13 \pm 2.9 \mathrm{a}$ & $34 \pm 7.6 \mathrm{~b}$ \\
\hline$H G$ & Cleistogenes squarrosa (Trin.) Keng.; Artemisia frigida Willd. & $23 \pm 2.9 b$ & $12 \pm 4.1 \mathrm{a}$ & $32 \pm 7.5 b$ \\
\hline \multicolumn{5}{|l|}{2006} \\
\hline RA & Leymus chinensis (Trin.) Tzvel. & $44 \pm 2.3 \mathrm{a}$ & $10 \pm 2.6 \mathrm{a}$ & $75 \pm 4.4 \mathrm{a}$ \\
\hline LG & Leymus chinensis (Trin.) Tzvel.; Cleistogenes squarrosa (Trin.) Keng & $40 \pm 4.6 \mathrm{a}$ & $11 \pm 2.0 \mathrm{a}$ & $59 \pm 6.2 \mathrm{a}$ \\
\hline MG & Artemisia frigida Willd.; Cleistogenes squarrosa (Trin.) Keng & $22 \pm 4.1 \mathrm{~b}$ & $13 \pm 1.7 \mathrm{a}$ & $30 \pm 7.1 b$ \\
\hline$H G$ & Cleistogenes squarrosa (Trin.) Keng; Artemisia frigida Willd. & $21 \pm 1.8 b$ & $11 \pm 4.3 \mathrm{a}$ & $18 \pm 2.7 \mathrm{c}$ \\
\hline
\end{tabular}

${ }^{1} \mathrm{RA}$ indicates reference area; LG, light grazing; MG, moderate grazing; and $\mathrm{HG}$, heavy grazing.

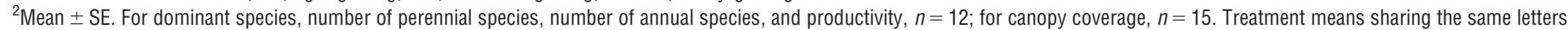
within response variable were not significantly different at $P \leq 0.05$.

RA was replaced by a drought-enduring grass (Cleistogenes squarrosa) and a short semishrub (Artemisia frigida) in the area around settlement (zones of HG); therefore, increasing grazing intensity resulted in significantly changed plant species composition even across this relatively short gradient of $4 \mathrm{~km}$ (Table 2).

For 2004, productivity in RA and LG treatments was higher $(P<0.05)$ than the other two treatments, but there were no significant differences between RA and LG $(P>0.05)$ or between MG and HG $(P>0.05$; Fig. 1). For 2006, the RA treatment had the highest $(P<0.05)$ aboveground biomass, and there were no significant differences among the other three treatments $(P>0.05)$. Belowground biomass did not follow the same trends as aboveground biomass; the highest values were in the treatments of LG and MG for 2004, and they were significantly higher than that of the HG treatment $(P<0.05)$ (Fig. 1). There were no differences in belowground biomass between RA and the other three treatments $(P>0.05)$. For 2006, values of belowground biomass among four treatments were the same $(P>0.05)$ and they were not affected by the grazing treatments (Fig. 1).

Canopy coverage of perennial grasses declined with grazing intensity and showed the same trend in both 2004 and 2006 (Fig. 2). Perennial grasses had the highest $(P<0.05)$ coverage for RA, and the lowest $(P<0.05)$ for MG and HG. Coverage of shrubs showed the opposite tendency, followed by the decrease of perennial grasses among four treatments (Fig. 2). The similar trend in both years showed that shrubs had the highest $(P<0.05)$ coverage for the HG treatment, and the lowest values $(P<0.05)$ in the area without grazing.

\section{Heights of Dominant Species}

In both 2004 and 2006, the heights of five main species along the grazing gradient, except Stipa grandis, declined with an increase in grazing disturbance (Table 3). In the area around the residences (HG), Leymus chinensis did not form reproductive offshoots in either 2004 or 2006. Conversely, A. frigida had no reproductive offshoots in the area without grazing intensity (RA). Neither C. squarrosa nor $P$. acaulis produced reproductive stems among different grazing intensity treatments during the period of investigation. S. grandis did not form reproductive offshoots in RA in either year, or in HG in 2004 (Table 3).
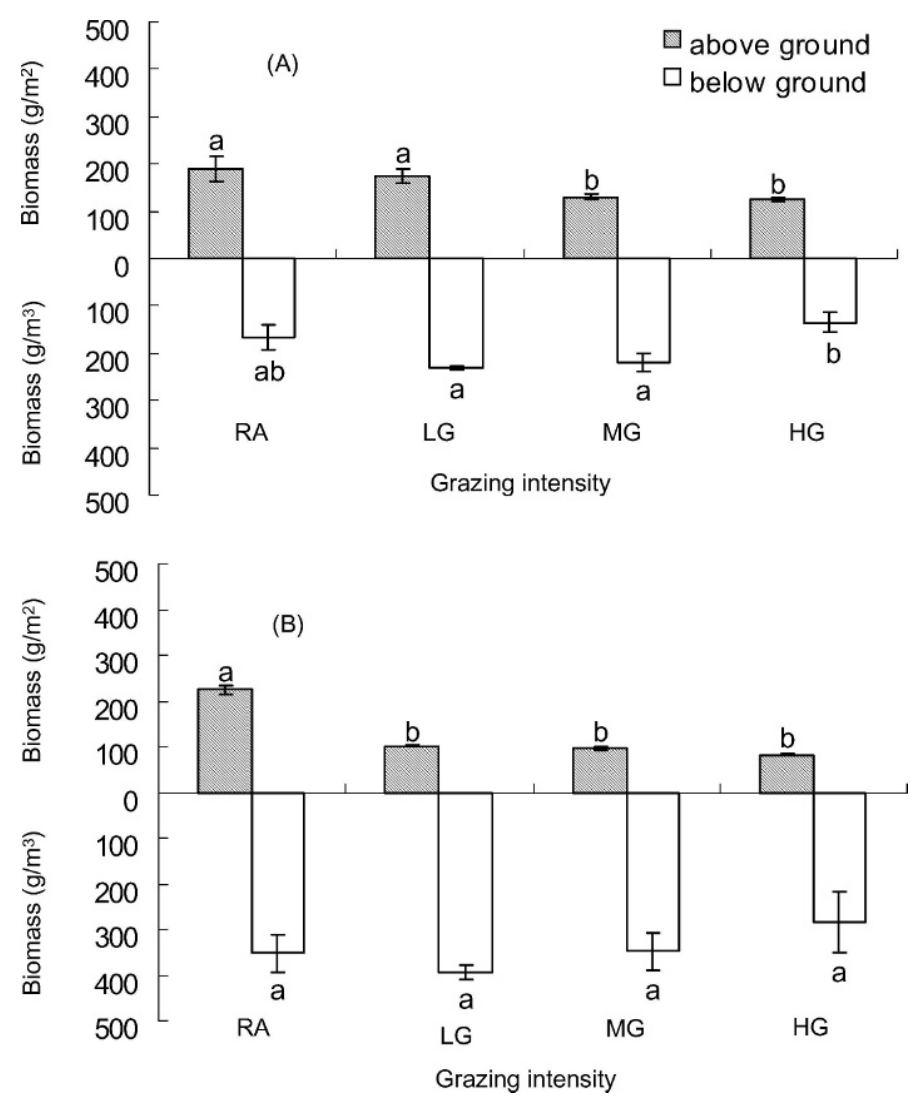

Figure 1. Mean $( \pm S E)$ above and belowground biomass $\left(g \cdot \mathrm{m}^{-2}\right)$ in response to grazing intensities for the years of A, 2004 and $\mathbf{B}, 2006$ (August 2004 and 2006). Error bars show errors of the means. Means $(n=9)$ sharing the same letters were not significantly different $(P \leq 0.05)$. RA indicates reference area; $\mathrm{LG}$, light grazing; $\mathrm{MG}$, moderate grazing; and $\mathrm{HG}$, heavy grazing. 

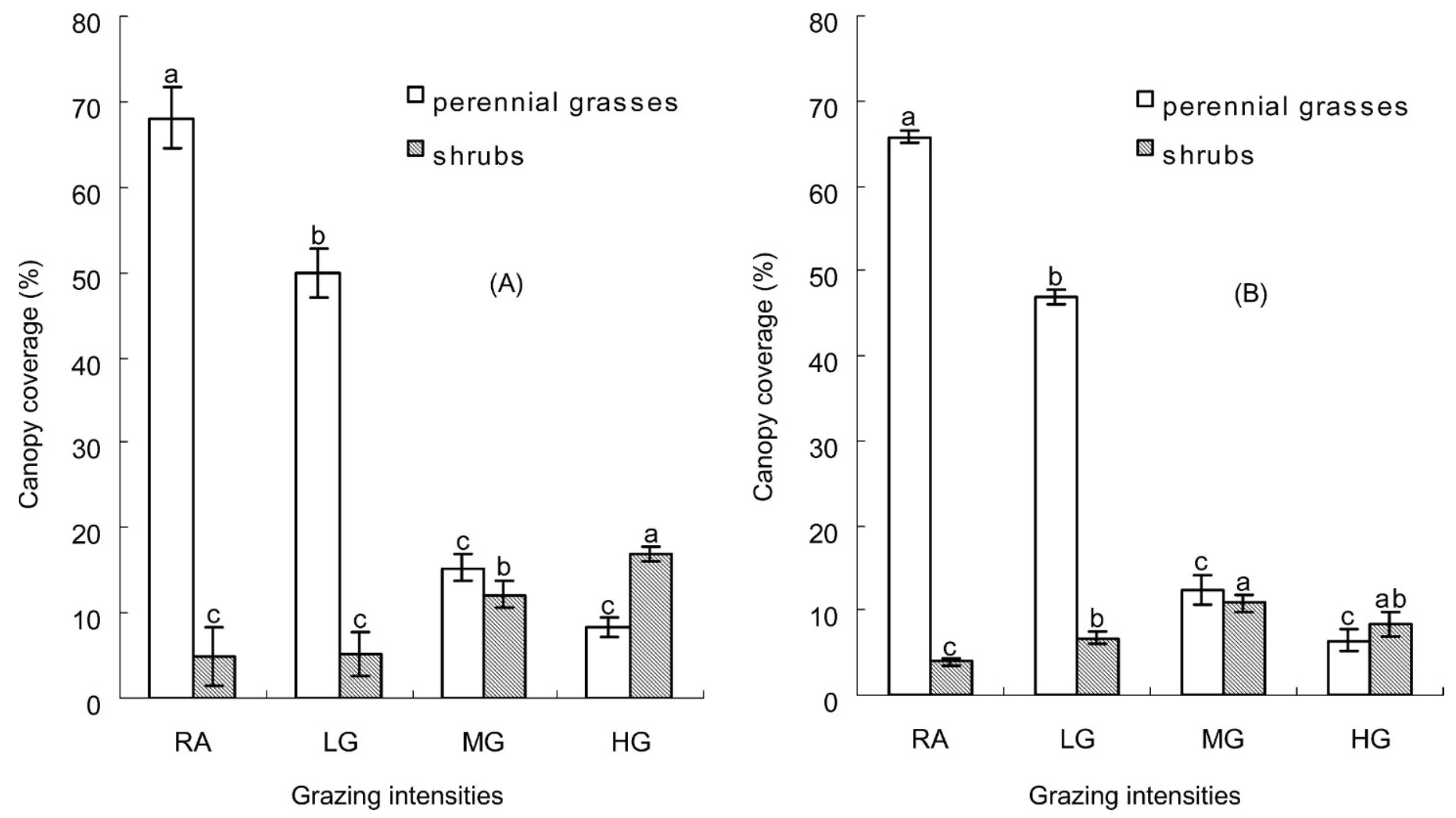

Figure 2. Mean ( $\pm \mathrm{SE}$ ) canopy coverage (\%) of perennial grasses vs. woody plants (shrubs and subshrubs) under the different grazing intensities for the years of A, 2004 and B, 2006 (August 2004 and 2006). Error bars show errors of the means. Means $(n=12)$ sharing the same letters were not significantly different $(P \leq 0.05)$. RA indicates reference area; LG, light grazing; MG, moderate grazing; and HG, heavy grazing.

\section{Aboveground Vertical Structure}

Aboveground biomass in RA in the $0-5 \mathrm{~cm}$ layer was less $(P<0.05)$ than in the other three treatments (Fig. 3$)$. In the layers of $5-10 \mathrm{~cm}, 10-15 \mathrm{~cm}, 15-20 \mathrm{~cm}, 20-25 \mathrm{~cm}, 25-$ $30 \mathrm{~cm}$, and $30-35 \mathrm{~cm}$, the aboveground biomass decreased from RA to the residential area (HG treatment). Most of the aboveground biomass occurred in the lowest layer except for treatment RA, where it occurred in the $5-10-\mathrm{cm}$ layers. In the 10-15-cm layer, the biomass in RA was higher than the other three treatments $(P<0.05)$, and biomass in both MG and HG was lower than that in LG, with no difference between $\mathrm{MG}$ and $\mathrm{HG}(P>0.05)$. Biomass in RA and LG in the layers above $20 \mathrm{~cm}$ was similar $(P>0.05)$, and was higher than in the other two grazing intensities $(P<0.05)$.

\section{Belowground Vertical Structure}

Root distributions in the soil profile for the four grazing intensities had the highest concentrations at the top and

Table 3. Heights of main populations (cm) in response to grazing intensity for 2004 and 2006.

\begin{tabular}{|c|c|c|c|c|c|c|c|c|c|c|}
\hline & \multicolumn{2}{|c|}{ Leymus chinensis } & \multicolumn{2}{|c|}{ Stipa grandis } & \multicolumn{2}{|c|}{ Cleistogenes squarrosa } & \multicolumn{2}{|c|}{ Artemisia frigida } & \multicolumn{2}{|c|}{ Potentilla acaulis } \\
\hline & $\mathrm{H}_{\mathrm{Re}}{ }^{1}$ & $\mathrm{H}_{\mathrm{Le}}$ & $\mathrm{H}_{\mathrm{Re}}$ & $\mathrm{H}_{\mathrm{Le}}$ & $\mathrm{H}_{\mathrm{Re}}$ & $\mathrm{H}_{\mathrm{Le}}$ & $\mathrm{H}_{\mathrm{Re}}$ & $\mathrm{H}_{\mathrm{Le}}$ & $\mathrm{H}_{\mathrm{Re}}$ & $\mathrm{H}_{\mathrm{Le}}$ \\
\hline \multicolumn{11}{|l|}{2004} \\
\hline $\mathrm{RA}^{2}$ & 37.2 & 28.8 & - & 28.4 & - & 9.9 & - & 8.6 & - & 3.0 \\
\hline$L G$ & 48.1 & 23.5 & 48.1 & 32.3 & - & 6.9 & 27.7 & 7.8 & - & 2.6 \\
\hline$M G$ & 29.7 & 22.5 & 46.5 & 24.1 & - & 7.7 & 24.8 & 7.3 & - & 2.5 \\
\hline$H G$ & - & 12.9 & - & 6.5 & - & 6.1 & 14.9 & 3.4 & - & 2.3 \\
\hline \multicolumn{11}{|l|}{2006} \\
\hline RA & 39.3 & 26.1 & - & 19.6 & - & 9.3 & - & 3.3 & - & 1.3 \\
\hline$L G$ & - & 15.7 & 42.0 & 14.4 & - & 6.4 & 11.5 & 3.5 & - & 1.6 \\
\hline$M G$ & - & 11.7 & 22.0 & 8.5 & - & 5.0 & 17.6 & 4.1 & - & 2.0 \\
\hline$H G$ & - & 8.3 & 19.2 & 11.4 & - & 5.0 & 14.1 & 3.5 & - & 1.9 \\
\hline
\end{tabular}

${ }^{1} \mathrm{H}_{\mathrm{Re}}$ indicates reproductive height; $\mathrm{H}_{\mathrm{Le}}$, foliage layer height.

${ }^{2} \mathrm{RA}$ indicates reference area; $\mathrm{LG}$, light grazing; $M G$, moderate grazing; and $\mathrm{HG}$, heavy grazing. 

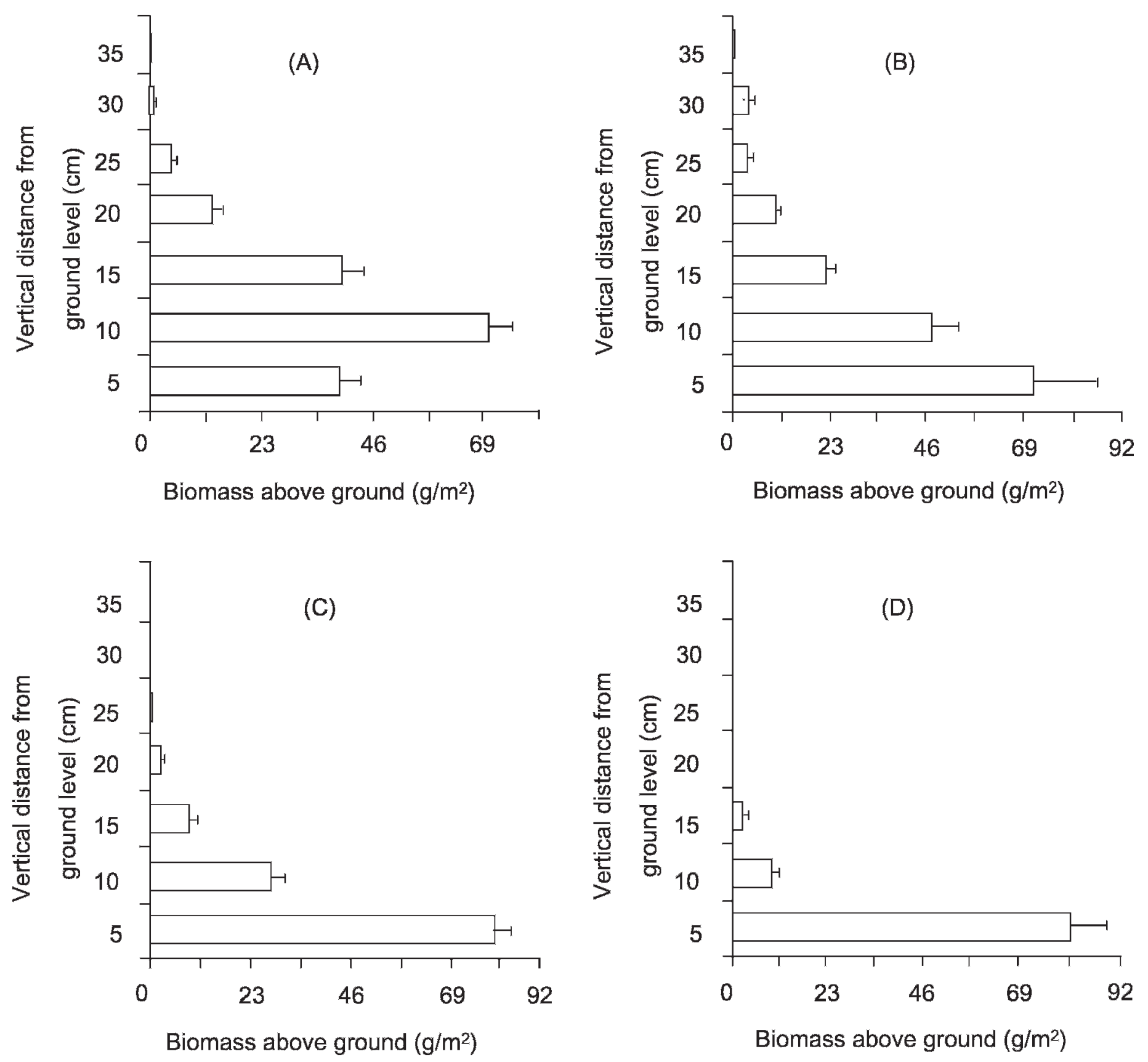

Figure 3. Mean $( \pm \mathrm{SE})$ aboveground biomass $\left(\mathrm{g} \cdot \mathrm{m}^{-2}\right)$ for different height layers in response to grazing intensities (August 2004): A, reference area, B, light grazing, C, moderate grazing, and $\mathbf{D}$, heavy grazing. Error bars show errors of the means. Means $(n=9)$ sharing the same letters were not significantly different $(P \leq 0.05)$.

decreased with depth (Fig. 4). In the top $10 \mathrm{~cm}$ and $10-20 \mathrm{~cm}$ of soil, root biomass in the RA and LG treatments was similar and values of $M G$ and $H G$ were at the same level $(P>0.05$; Fig. 4). Roots in 10-20-cm soil increased with more grazing effects, and percentages of total biomass below ground divided by roots accumulated within $10-20-\mathrm{cm}$ soil were $14 \%$ and $16 \%$ for RA and $\mathrm{LG}$ and $19 \%$ and $21 \%$ for $\mathrm{MG}$ and $\mathrm{HG}$, respectively. For all four grazing treatments, belowground biomass in the 20-30-cm and 30-100-cm layers was nearly the same $(P>0.05$; Fig. 4$)$.

\section{DISCUSSION}

Plant populations in the degraded arid steppe dominated by Leymus chinensis typically show signs of replacement under grazing (Wang and Li 1995). Uneven utilization tends to lead to different degraded conditions (Snyman 1998; Garcia et al. 2003) with resulting stability of degraded states lasting for months once the rangeland structure of patches with different conditions is established. We found the same phenomenon in this study. 


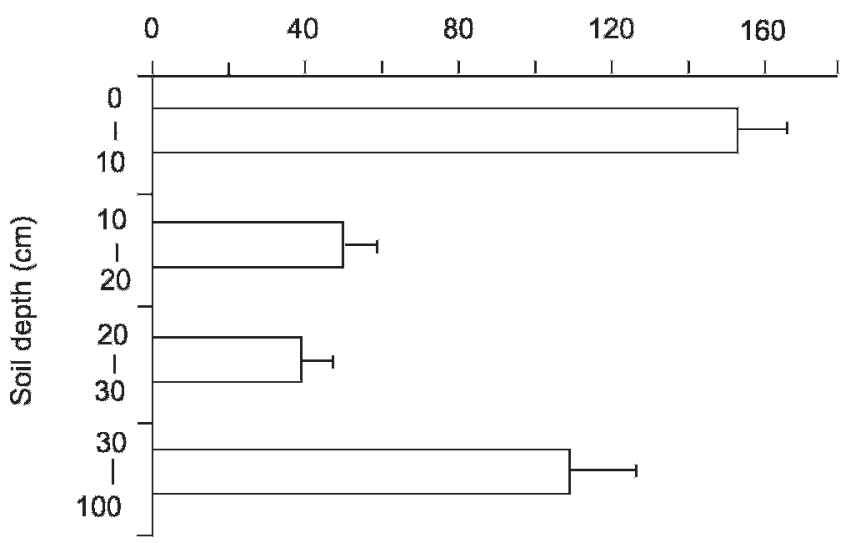

(A)

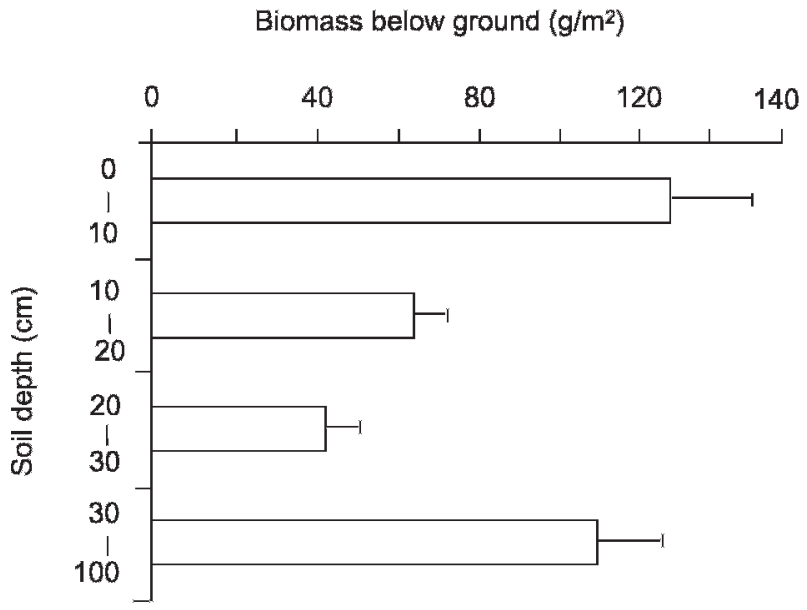

(C)

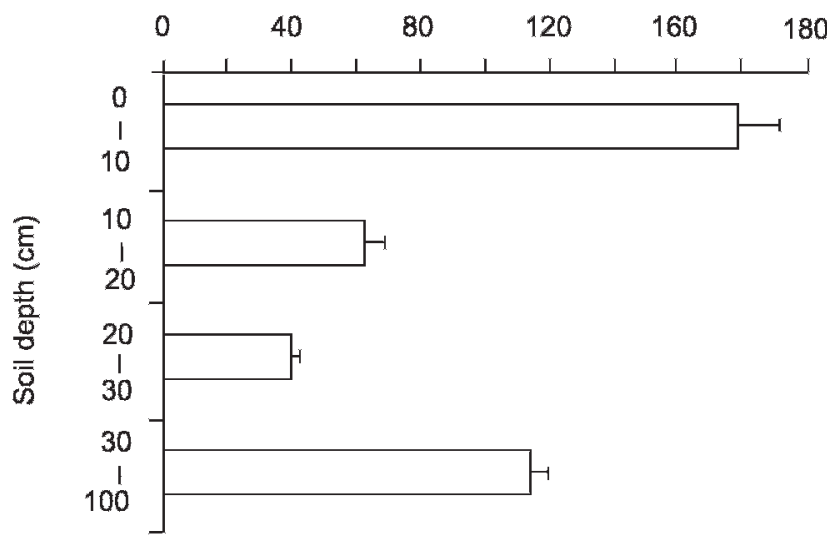

(B)

Biomass below ground $\left(\mathrm{g} / \mathrm{m}^{2}\right)$

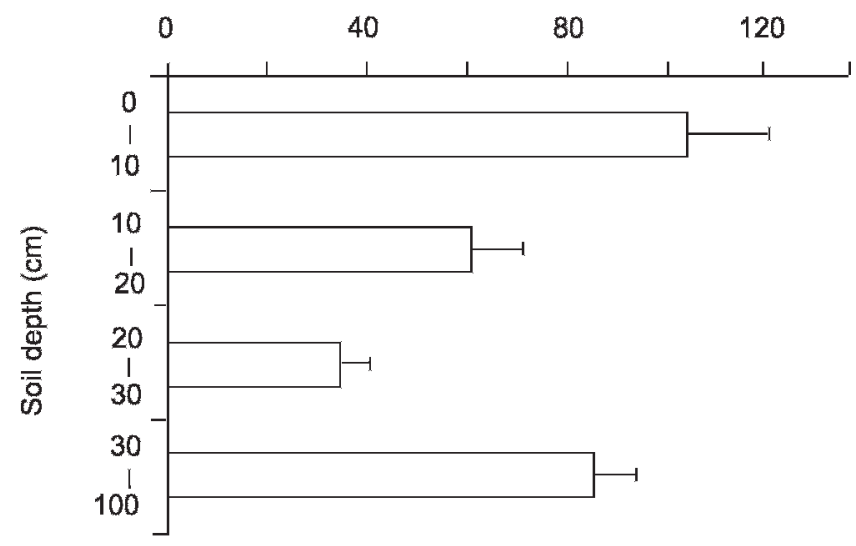

(D)

Figure 4. Mean ( $\pm \mathrm{SE}$ ) belowground biomass $\left(\mathrm{g} \cdot \mathrm{m}^{-3} ; n=5\right)$ distribution for different soil depths in response to grazing intensities (August 2004): A, reference area, B, light grazing, $\mathbf{C}$, moderate grazing, and $\mathbf{D}$, heavy grazing. Error bars show errors of the means. Means $(n=9)$ sharing the same letters were not significantly different $(P \leq 0.05)$.

In most cases, degraded states on $L$. chinensis-dominant steppe show a decline in the dominance of high-quality perennial grasses that are gradually replaced by annual saline herbs; the change in community structure also tends to reduce soil conditions toward more saline and alkaline types (Wang and Li 1995). Vegetation is short and mainly of colonial propagation in the area under heavy grazing pressure (Table 3). The areas with less-intensive grazing had higher productivity (Fig. 1), which supports the conclusions by Garcia et al. (2003). Most researchers argue that primary productivity becomes more seasonally variable with increased degradation (Wiegand et al. 2004; Snyman 2005). Therefore, productivity and quality of forage, as well as the abundance and diversity of species, are seriously affected by changes in spatial structure that occur in response to excessive disturbance and degradation.

Although heavy grazing causes a reduction in the competitive abilities of herbaceous plants, it has little effect on the growth of shrubs (Li and Li 2002; Fig. 2). Artemisia frigida is quite common in the study area and is the dominant species in heavily grazed communities (Table 2). It adapts to heavy grazing by changing the growth pattern from upright to prostrate and increasing the number of shoots and adventitious roots to absorb more nutrition ( $\mathrm{Li}$ and $\mathrm{Li}$ 2002). The sharp decrease in community productivity following a change in dominant species indicates that an undesirable transition has occurred in the community (Friedel et al. 2003); we found such a shift from $L$. chinensis steppe into a shrub community (Fig. 2).

We assume this resulted in more intense competition between shrubs and herbaceous species for water and nutrients. Typically, herbaceous plants can confront more challenges (Hooper and Vitousek 1997; Hooper 1998) from fertility, habitat, and disturbance. Structural homogeneity of rangeland often is destroyed and soil erosion intensified following the reduction of herbaceous plants' dominance (Snyman 1998). A common end result of these competitive processes is the runoff of water and nutrients, finally leading to rangeland degradation (Tongway et al. 2003). Our experimental results indicated that all plant species, whether palatable or not, became smaller in size with rangeland degradation under intensive utilization 
(Table 3), which is concordant with the results of Wang et al. (2000).

Leymus chinensis is the main component of rhizomatous grasses and its decrease in size is the most obvious compared to other plant populations. In the areas of intensive disturbance, L. chinensis did not flower. Reproductive branch heights of Stipa grandis in LG and MG were similar. However, S. grandis in RA and HG did not form reproductive branches, which indicated that grazing might be beneficial in forming reproductive branches of $S$. grandis. Reproductive growth would be restricted if grazing were totally forbidden, but it would obviously not affect colonial growth (Gibson and Brown 1991). Both reproductive growth and colonial growth would be adversely influenced in areas of heavy grazing.

With plant community degradation, A. frigida had reduced heights along with other plant species. Nevertheless, the 2-yr average values for ratios of reproductive stem height to foliage layer height were $0,3.42,3.85$, and 4.21 units, respectively. We are of the opinion that under heavy grazing resulting in degraded states, A. frigida could complete its life cycle with limited environmental resources, thus ensuring a competitive advantage during the transition of dominant species in the community.

The leaf layer height of Potentilla acaulis decreased moderately along the degradation gradient (Table 3). Some researchers suggest that this species employs strategies of selfadjustment in accordance with the existing environmental conditions ( $\mathrm{Li}$ and $\mathrm{Li}$ 2002). When the environmental resources are abundant, competition and interference from other plant species are critical and the ability to endure disturbance would be increased. Under relatively poorer environmental conditions, its leading strategy would be pressure endurance, because it has to allocate the main resources to survival. The above inference might imply the last protective barrier against further degradation on typical steppe is $P$. acaulis.

Vertical stratification of a community is an ecological indicator of environmental quality. The ecological significance of this environmental feature lies in the competition for sunlight, water, and mineral nutrition utilized through stratified resources (Sparrow et al. 2003). Therefore, the more complex the stratification, the more fully the environmental resources are used. In this study the majority of aboveground biomass was produced in the $5-15-\mathrm{cm}$ layer in treatment RA, compared to most accumulated production in the $0-5-\mathrm{cm}$ layer in the other three treatments (Fig. 3). The plant community of RA is of higher production and stability, and the structural characteristics in RA might be beneficial for the efficient use of light and space. In the four treatments, the ratios of aboveground biomass in the $0-5-\mathrm{cm}$ layer to the total mass were $23.5 \%, 45.0 \%, 65.5 \%$, and $87.5 \%$, respectively, which demonstrates that grazing intensity negatively affected plant vertical growth. The structural degradation of plant populations might cause insufficient and uneven resource utilization, thereby leading to degraded vegetation states.

In this study of the belowground biomass, most of the roots were distributed in the top soil layers. These high concentrations of roots could be due to increased concentrations of nutrients in these surface soil layers (Montani et al. 1996). Animal behavior, including feeding, nutrition, evacuation, and trampling, changed the compaction, water content, and the soil nutrients, perhaps forming a more fitting environment for the survival of roots (Sparrow et al. 2003). Severe grazing greatly changed the species composition of the plant community in this study (Table 2; Fig. 2). However, the root biomass between RA and the area surrounding the settlement (HG treatment) showed no difference $(P>0.05$; Fig. 1$)$. The result was not consistent with that of Snyman (1998), who concluded that rangeland in good condition will have both high above- and belowground biomass, and with the above- and belowground biomass decreasing with degradation. According to the results of this study, variation in species composition of plant communities is not the direct cause affecting root biomass, and further studies on grazing intensity response should be conducted to clarify the relationships between these elements.

Overall, grazing intensities were classified as reference area (RA), light (LG), moderate (MG), and heavy (HG) according to the vegetation utilization across the study area. Vegetation around a residential area showed significant signs of excessive use, even in a degraded state, compared to regions farther removed from settlement. Along this grazing gradient, vegetation changed from the original dominant species Leymus chinensis to a semi-subshrub species Artemisia frigida when moving from the reference area (RA) to the region around the settlement (HG). It is likely that these damaging grazing patterns have continued for three decades. Canopy coverage, aboveground productivity, and the number of perennial species declined toward the residential area. Heights of five dominant species, except for Stipa grandis, declined with increasing grazing intensity. Thus, heavy grazing caused a reduction in the competitive abilities of herbaceous plants. Aboveground vertical structure in the RA treatment showed more resilience than in the other treatments, and we are of the opinion that grazing intensity negatively affected plant vertical growth. Root biomass in the top $1 \mathrm{~m}$ of soil showed no difference $(P>0.05)$ between the RA treatment and the area immediately around settlement (HG).

\section{MANAGEMENT IMPLICATIONS}

The study showed that poor management of livestock grazing on rangelands in an arid steppe area can cause undesirable transitions in plant communities. Quality and distribution of heterogeneous grasslands in this region were changed by the nonequilibrium rangeland grazing. Present patterns of rangeland use have had disastrous effects on the sustainable development of rangeland ecosystems, especially to the grasslands around settlements. Rangeland degradation is continuing, which will pose a grave threat both to animal production and ecological security. Therefore, uneven utilization to grasslands and long-term inefficient management are the crux of the local problem.

In practice, viable options for grassland management, such as excluding grazing livestock and use of a rotational grazing system, are available ways to restore vegetation impacted by continuous grazing. However, few data are available for the rational development of these grassland management methods. Issues discussed in this study are common illustrations that reflect the vegetation conditions under domestic rangeland use; therefore, they could be considered basic references for the 
improvement of local rangeland condition, animal husbandry, and ecological security.

\section{ACKNOWLEDGMENTS}

We are grateful to many colleagues in Inner Mongolia Agricultural University and China Agriculture University for assistance with field experiments. Drs Bob Clements, Richard Dawson, Marina Knight, and Walter Willms made useful comments and the revisions of English expressions on the draft manuscript.

\section{LITERATURE CITED}

BaO, W., and 0. Chen. 1999. Procedures and characteristics of ecosystem degradation. Chinese Journal of Ecology 18:36-42.

Belsky, A. J. 1987. The effect of grazing: confounding of ecosystem, community, and organism scales. American Naturalist 129:777-783.

Chang, H. N., and J. X. XIA. 1994. Grazing systems of grassland and evaluations. Foreign Zootechny-Grassland Forage 4:9-14.

Du, Q. L. 2006. Strategies of sustainable development of Chinese grassland. Beijing, China: China Agricultural Press. 119 p.

Du Preez, C. C., and H. A. Snyman. 1993. Organic matter content of a soil in a semiarid climate with three long-standing veld conditions. African Journal of Range and Forage Science 10:108-110.

Friedel, M. H., A. D. Sparrow, J. E. Kinloch, and D. J. Tongway. 2003. Degradation and recovery processes in arid grazing lands of central Australia. Part 2: vegetation. Journal of Arid Environments 55:327-348.

Garcia, F., P. Carrére, J. F. Soussana, and R. T. Baumont. 2003. How do severity and frequency of grazing affect sward characteristics and the choices of sheep during the grazing season? Grass and Forage Science 58:138-150.

GiBson, C. W. D., And V. K. Brown. 1991. The effects of grazing on local colonization and extinction during early succession. Journal of Vegetation Science 2:291-300.

Hooper, D. U. 1998. The role of complementarity and competition in ecosystem responses to variation in plant diversity. Ecology 79:704-719.

Hooper, D. U., And P. M. Vitousek. 1997. The effects of plant composition and diversity on ecosystem processes. Science 277:1302-1305.

KraAis, T., And S. J. Milton. 2006. Vegetation changes (1995-2004) in semi-arid Karoo shrubland, South Africa: effects of rainfall, wild herbivores and change in land use. Journal of Arid Environments 64:174-192.

LI, J. H., AND Z. Q. LI. 2002. Clonal morphological plasticity and biomass allocation pattern of Artemisia frigida and Potentilla acaulis under different grazing intensities. Acta Phytoecologica Sinica 26(4):435-440.

LI, Y., AND S. WANG. 1999. Influences of grazing towards grassland vegetations. Grassland of China 3:11-19.

LIA0, G. F., AND Y. L. JiA. 1996. Grassland resources in China. Beijing, China: Science and Technology Press of China. $37 \mathrm{p}$.

Montani, T., C. A. Busso, O. A. Fernández, and R. E. Brevedan. 1996. Production and nitrogen cycling in an ecosystem of Eragrostis curvula in semi-arid Argentina. 1. Plant biomass and productivity. Acta Oecology 17:151-162.
O'Connor, T. G., L. M. Haines, and H. A. Snyman. 2001. Influence of precipitation and species composition on biomass of a semi-arid African grassland. Journal of Ecology 89:850-860.

Pel, X. C., and H. R. Xue. 1998. SAS and its utilizations. Beijing, China: China Agricultural Press. $81 \mathrm{p}$.

ReN, J. Z. 1998. Research methods of grassland science. Beijing, China: China Agricultural Press. $27 \mathrm{p}$.

Snyman, H. A. 1998. Dynamics and sustainable utilization of the rangeland ecosystem in arid and semi-arid climates of southern Africa. Journal of Arid Environments 39:645-666.

Snyman, H. A. 2005. Rangeland degradation in a semi-arid South Africa. I: influence on seasonal root distribution, root/shoot ratios and water-use efficiency. Journal of Arid Environments 60:457-481.

Snyman, H. A., and C. C. Du Preez. 2005. Rangeland degradation in a semi-arid South Africa: 2. influence on soil quality. Journal of Arid Environments 60:483-507.

Sparrow, A. D., M. H. Friedel, and D. Tongway. 2003. Degradation and recovery processes in arid grazing lands of central Australia. Part 3: implications at landscape scale. Journal of Arid Environments 55:349360.

Su, Y., Y. LI, J. CUI, AND W. ZHAo. 2005. Influences of continuous grazing and livestock exclusion on soil properties in a degraded sandy grassland, Inner Mongolia, northern China. Catena 59:267-278.

Swemmer, A. M., A. K. Knapp, and H. A. Snyman. 2007. Intra-seasonal precipitation patterns and aboveground productivity in three perennial grasslands. Journal of Ecology 95:780-788.

Tongway, D. J., A. D. Sparrow, and M. H. Friedel. 2003. Degradation and recovery processes in arid grazing lands of central Australia. Part I: soil and land resources. Journal of Arid Environments 55:302-326.

Van der westhuizen, H. C., H. A. Snyman, and H. J. Fouché. 2005. A degradation gradient for the assessment of rangeland condition of a semi-arid sourveld in southern Africa. African Journal of Range and Forage Science 22:47-58.

Van der westhuizen, H. C., H. A. Snyman, W. L. J. Van Rensburg, and J. A. J. Potgieter. 2001. The qualification of grazing capacity from grazing and production values for forage species in semi-arid grasslands of southern Africa. African Journal of Range and Forage Science 18:43-52.

Wang, R. Z. 2004. Responses of Leymus chinensis (Poaceae) to long-term grazing disturbance in the Songnen grasslands of north-eastern China. Grass and Forage Science 59:191-195.

WANG, R. Z., AND J. D. LI. 1995. Study of growth and decline model of populations during the degraded succession grazed on Leymus chinensis steppe. Plant Ecology 19:170-174.

Wang, W., C. Z. Liang, Z. L. LIU, AND D. Y. HaO. 2000. Analysis of plant individuals behaviors in the process of grassland community degradation and recovery succession. Plant Ecology 24:268-274.

Wiegand, T., H. A. Snyman, K. Kellner, and J. M. Paruelo. 2004. Do grassland have a memory: modeling phytomass production of a semi-arid South African grassland. Ecosystems 7:243-258.

Xin, X., and N. H. Jiang. 2001. Principles of statistics. Beijing, China: China Agricultural University Press. 307 p. 